\title{
A new species of Leptolalax (Anura: Megophryidae) from the sacred groves of Mawphlang, Meghalaya, north-eastern India
}

\author{
INDRANEIL DAS ${ }^{1,3}$, RONALD K. LYNGDOH TRON ${ }^{2}$, DUWAKI RANGAD ${ }^{2} \&$ RUPA N. K. HOOROO ${ }^{2}$ \\ ${ }^{1}$ Institute of Biodiversity and Environmental Conservation, Universiti Malaysia Sarawak, 94300, Kota Samarahan, Sarawak, \\ Malaysia \\ ${ }^{2}$ Developmental Biology Laboratory, Department of Zoology, North Eastern Hill University, Mawlai, Mawkynroh, Shillong 793 022, \\ Meghalaya, India \\ ${ }^{3}$ Corresponding author.E-mail: idas@ibec.unimas.my
}

\begin{abstract}
A new species of megophryid frog of the genus Leptolalax is described from the sacred groves of Mawphlang, East Khasi Hills, north-eastern India. L. khasiorum new species, is compared with congeners from India and other parts of south-east Asia. The new species is diagnosable in showing the following combination of characters: SVL 24.5-27.3 (mean 25.63 $\pm 0.61 \mathrm{SE}$ ) $\mathrm{mm}$ in a sample of four adult males; 31.2-33.4 (mean 32.50 $\pm 0.67 \mathrm{SE}$ ) $\mathrm{mm}$ in a sample of three females; dorsum with fine scattered tubercles; eyelids with tubercles; tympanum and supratympanic fold distinct; macroglands, including preaxillary, pectorals and ventrolateral glands present; Finger I > II; toe tips not dilated, bearing dermal fringes; dorsum with dark blotches; flanks with large dark blotches; dark tympanic mask present; venter lacking dark blotches; labial bars present and limbs with dark cross-bars.
\end{abstract}

Key words: Leptolalax khasiorum sp. nov. Megophryidae, Khasi Hills, north-eastern India

\section{Introduction}

The genus Leptolalax Dubois, 1980 (Anura: Megophryidae) is widespread in subtropical and tropical parts of south-east Asia and east Asia, with a range from southern China and north-eastern India, through Myanmar, Thailand, Cambodia, Vietnam and Peninsular Malaysia, to Borneo (Inger et al., 1999; Iskandar \& Colijn 2000; Frost 2009). At present, 24 species are considered valid (Frost 2009; Matsui et al. 2009; Rowley \& Trung 2009; Table 1).

We conducted an amphibian diversity assessment in the month of March 2009, at Mawphlang, a sacred grove in the East Khasi Hills, Meghalaya state, north-eastern India (Fig. 1), and report here a hitherto undescribed species of Leptolalax (subgenus Lalax, for reasons detailed in the diagnosis), which we name in this paper. Lathrop (1997) noted that the genus, as presently constituted, lack identifiable apomorphies. Delorme et al. (2006) enumerated apomorphic characters to diagnose Leptolalax from Leptobrachella, and while recognizing two nominal subgenera within the former: a northern lineage, Lalax, argued to be diagnosed on apomorphies, and a southern lineage, Leptolalax, containing taxa showing plesiomorphic residue of Leptolalax (sensu lato), after the recognition of Lalax (see Frost 2009).

\section{Material and methods}

The four males and three females from the type series were collected from moist interstices of rocks along a partially dried-up stream bed during the day and early evening. They were photographed prior to euthanasia, 